\title{
'FROM FAIREST CREATURES WE DESIRE INCREASE'
}

\section{Joyelle McSweeney}

All night, I've been rubbing two nickels together, Hoping they would multiply, You call with your news Just as twin, twelve-year-old Hawaiian girls Begin a modified hula on a confused, dude Ranch episode of the Mickey Mouse Club, circa Nineteen-Fifty-Two. Annette Funicello looks so Zaftig in her boots and vest, her close-cropped curls About to blossom and unseat her ears. We hang up To Bette Davis in a double role, two sisters You can tell apart by their poor girl/rich girl hats. If I had your luck, I'd buy the rights to this, produce The remake. I'd play both parts, shoot each scene twice, Shout orders through a megaphone. Of course, the strain Would get to be too much; I'd leave the set For refuge in some bungalow-cum-dope-den, Alas, miscarry. Meanwhile, back at the lot, I've canceled my contract. I won't return My calls. When I meet myself in the street, I say You're finished. 